\title{
Real frontier in clinical applications of regenerative medicine
}

\section{Kazuo Tsubota}

In this thematic series, Real Frontier in Clinical Applications of Regenerative Medicine in Inflammation and Regeneration four leading research teams showcase their review articles as the forefront of regenerative medicine in clinical applications in Japan. We are very proud of the progress made over the last several years.

As we know, there are three kinds of approaches to regenerative medicine. The first is cell therapy, the second is protein, and the third applies artificial materials. One such technique that was developed in Japan using a local injection of a gelatin hydrogel impregnated with the protein fibroblast growth factor-2 is gaining in popularity, and the clinical application of this method is expanding. Dr. Kuroda from Kyoto University reviewed the clinical application of injectable growth factor for bone regeneration, and his review describes the progress of injectable growth factor, not implanting regenerative tissue, but supporting the regeneration inside the body.

From Keio University, Drs. Hatou and Shimmura reviewed corneal endothelial cell derivation methods from embryonic stem (ES) and induced pluripotent (iPS) cells. Dr. Hatou has developed a method of regeneration from iPS cells to make endothelial cells, and it will be ready for the clinical application soon. They have taken their research seriously and formed a start-up company, Cellusion, Inc. The method can save sight for patients around the world who are suffering from corneal endothelial dysfunction.

The research led by Drs. Tsuchiya and Terai from Niigata University report on mesenchymal stem cell therapies for liver cirrhosis, which is now already clinically available. As described in the article, more than 50 clinical trials related to liver diseases have already been conducted or are underway.

Correspondence: tsubota@z3.keio.jp

Department of Ophthalmology, Keio University School of Medicine, Tokyo, Japan

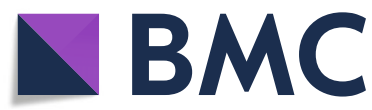

Leaders in the field of cardiac regenerative medicine are Drs. Fujita and Fukuda from Keio University who describe cell therapy using human iPS cell-derived cardiomyocytes for patients with severe heart failure. They are serious researchers on regeneration in cardiac medicine, and their review article shows the feasibility of their method for curing the patients. The start-up, Heartseed, Inc., was established to move that research forward.

Here, I am indebted to the contributors to this special issue for sharing their time and expertise and look forward to seeing further research flow from their work by providing clinical applications for regenerative medicine therapies.

\section{Author's contributions \\ The author read and approved the final manuscript.}

Competing interests

The author declares no competing interests.

Published online: 26 March 2020

\section{Publisher's Note}

Springer Nature remains neutral with regard to jurisdictional claims in published maps and institutional affiliations.

Ready to submit your research? Choose BMC and benefit from:

- fast, convenient online submission

- thorough peer review by experienced researchers in your field

- rapid publication on acceptance

- support for research data, including large and complex data types

- gold Open Access which fosters wider collaboration and increased citations

- maximum visibility for your research: over $100 \mathrm{M}$ website views per year

At BMC, research is always in progress.

Learn more biomedcentral.com/submissions

(C) The Author(s). 2020 Open Access This article is licensed under a Creative Commons Attribution 4.0 International License, which permits use, sharing, adaptation, distribution and reproduction in any medium or format, as long as you give appropriate credit to the original author(s) and the source, provide a link to the Creative Commons licence, and indicate if changes were made. The images or other third party material in this article are included in the article's Creative Commons licence, unless indicated otherwise in a credit line to the material. If material is not included in the article's Creative Commons licence and your intended use is not permitted by statutory regulation or exceeds the permitted use, you will need to obtain permission directly from the copyright holder. To view a copy of this licence, visit http://creativecommons.org/licenses/by/4.0/. 